\title{
INCOME MOBILITY IN COSTA RICA, 2001-2007
}

\author{
Samuel Rowe (UMBC) ${ }^{1}$ \\ T.H. Gindling (UMBC and IZA) ${ }^{2}$ \\ Juan Diego Trejos (Universidad de Costa Rica) ${ }^{3}$
}

Recibido: 12/02/2014

Aprobado: 23/05/2014

\begin{abstract}
In this paper we study year-to-year intra-generational income mobility in Costa Rica. To do so we use a panel data set constructed from the Household Surveys for Multiple Purposes (2001-2007) that allows us to follow the same households and persons from year-to-year. We find that there is substantial year-to-year income mobility in Costa Rica, especially in the middle of the income distribution. We also identify the factors that most affect yearto-year income mobility in Costa Rica. We find that per capita income is conditionally convergent; low-income families are more likely to experience an increase in income than are high-income families. Aside from initial per capita income, the three most important factors that explain changes in per capita household income in Costa Rica are, in order of importance: (1) changes in the employment status of household members; (2) changes in the number of dependents (children, elderly and other non-working members) in the household; and (3) the education of household members, especially the household head.
\end{abstract}

KEY WORDS: MOBILITY, INCOME DISTRIBUTION, LABOR MARKET, EDUCATION, FAMILY STRUCTURE

\section{RESUMEN}

En este artículo se estudia la movilidad interanual o intrageneracional del ingreso en Costa Rica. Para ello, se utilizan datos de panel construidos a partir de las Encuestas de Hogares de Propósitos Múltiples correspondientes a los años del 2001 al 2007, que permiten darle seguimiento a los mismos hogares y personas año con año. Se encontró que existe una sustancial movilidad de ingresos interanual, particularmente en el segmento medio de la distribución del ingreso. También se identificaron los factores que más afectan la movilidad interanual del ingreso en Costa Rica. Se encontró que el ingreso per cápita es condicionalmente convergente, esto es, las familias de bajos ingresos son más propensas a experimentar aumentos mayores en sus ingresos que las familias de alto ingreso. Además del ingreso per cápita inicial, los tres factores más importantes que explican los cambios en los ingresos per cápita en Costa Rica son los siguientes, en orden de importancia: (1)

1 University of Maryland-Baltimore County (UMBC) and Institute for the Study of Labor (IZA),USA srowe4@umbc.edu

2 University of Maryland-Baltimore County (UMBC) and Institute for the Study of Labor (IZA), USA, tgindlin@umbc.edu 
cambios en la situación de empleo de los miembros del hogar; (2) cambios en el número de dependientes (niños, adultos mayores y miembros inactivos económicamente) en la familia; y (3) la educación de los miembros, particularmente la del jefe del hogar.

PALABRAS CLAVES: MOVILIDAD, DISTRIBUCIÓN INGRESOS, MERCADO TRABAJO, EDUCACIÓN, COMPOSICIÓN FAMILIAR

\section{INTRODUCTION ${ }^{4}$}

Analyses and comparisons of the levels of income inequality and poverty at different points in time in developing countries are common, but comparisons of these static statistics hide important details about changes in family incomes that occur for individuals and households over time. At the micro level, the income of individual households can change dramatically over time, resulting in changes in poverty status and position in the distribution of income (Fields, Hernandez, Freije, \& Sanchez-Puerta, 2007). Even if the levels of income inequality do not change over time, the specific households at different points in the distribution of income will differ over time; a household that is in the bottom quintile one year may be in the second or third quintiles in another year. Research on income mobility in developing countries has been growing as panel data have become more available for these countries (Fields \& Sanchez-Puerta, 2010). This paper contributes to this literature by examining the magnitude and correlates of year-to-year intra-generational income mobility in Costa Rica from 2001 to 2007.

Understanding which factors affect absolute and relative income mobility is important for several reasons. This type of research can help identify those who need help and the factors that are associated with their economic struggles, which can contribute to the design of social safety nets and other policy interventions to protect the vulnerable (Baulch \& Hoddinott, 2000). Even if the level of income inequality remains the same, greater income mobility increases the incentives for individuals to invest in and improve their productivity and move up the income distribution. Studies that identify the characteristics that promote income mobility can therefore contribute to the design of policy interventions that increase both economic growth and improve equity.

The rest of this paper is divided into several sections. First, a literature review will discuss income mobility studies in Latin America. The next section will review the data and methodologies needed for an analysis of intra-generational income mobility at the micro-level. We then measure the extent of relative income mobility (changes in the relative position of the household in the distribution of income, i.e. among quintiles). Finally, we conduct a multivariate analysis of which households-with what characteristics-have the most or least absolute and relative income mobility.

\section{LITERATURE REVIEW}

Two major types of income mobility need to be distinguished. First, a distinction needs to be made between intra-generational and intergenerational income mobility. Intra-generational income mobility analyzes the dynamic evolution of income for an individual or household at two or

$4 \quad$ The creation of the panel data set used in this paper was financed through Canadian International Development Research Center (IDRC) research grant number 104242-001, administered by the Fundación Salvadoreña para el Desarrollo Económico y Social (FUSADES). We are grateful to Lisa Dickson for helpful comments. 
more points in time, while intergenerational income mobility focuses on the relationship between the income of parents and their children (Fields, 2008). This paper analyzes intra-generational income mobility. A second major distinction needs to be made between macro-economic and microeconomic income mobility studies. Macro-economic income mobility studies focus on the question of how much mobility exists, while micro-economic income mobility studies focus on the correlates and the determinants of income or positional change of recipient units such as households (Fields, 2008). This paper analyzes the income mobility of households in Costa Rica at the macro-level using transition matrices and at the micro-level using multivariate analysis.

Within micro-economic mobility there are additional issues to consider. First, there is a distinction between unconditional and conditional micro-mobility. Unconditional micro-mobility analysis focuses on how initial earnings relates to changes in earnings without holding other factors constant (Fields, 2011). Conditional micro-mobility analyzes the effects of the correlates of income mobility while holding other factors constant. The second issue that needs consideration is the concept of income. An analysis of absolute income mobility analyzes earnings changes in absolute earnings gains (Fields \& Sanchez-Puerta, 2010). Conversely, an analysis of relative income mobility seeks to observe the positional changes or quintile changes among units in various positions within the income distribution (Fields, 2008). This paper analyzes micro-economic conditional mobility in both absolute and relative terms.

The per capita income of a household can change because income changes, because the number of household members changes, or both (Fields, et al., 2003). Incomes of households derive from endowments of factors of production such as labor, land, physical capital, human capital (education, health, etc.) and social capital. "The allocation of endowments to activities, together with returns to endowments in these activities, generates income" (Baulch and Hoddinott, 2000, p.4). For example, an increase in the number of household members who enter the labor market or an increase in wages will both lead to an increase in household income. While changes in the allocation and prices of endowments can lead to income mobility, the level of endowments may also affect mobility. For example, greater endowments may reduce declines in household income when negative shocks occur because households may use endowments to stabilize incomes (for example, use savings or allocate more household members to the labor market). On the other hand, a higher level of endowments can also provide the funding for investments in new endowments such as human capital, health and physical capital and make it more likely that households will move up the income distribution.

Changes in the labor market status (employment, sector of employment, etc.) have been shown to have a very important impact on income mobility. For example, Fields et al. (2003) present evidence that changes in the employment status of the household head are more important than changes in household size in explaining income mobility in South Africa, Spain, Indonesia and Venezuela. Slon and Zuniga (2006) present evidence that in Costa Rica the most important determinant of mobility between poverty states is the employment status of the household head. Households where heads gained formal sector employment experience the largest income gains (Fields, et al. 2003). Employment transitions between industry sectors has also been found to be a significant determinant of income mobility (Fields, et al. 2007).

One of the strongest results in the literature is that endowments of education play an important role in income mobility. Ferreira, Messina, Rigolini, Lopez-Calva, Lugo, and Vakis (2013) find that education is strongly associated with upward mobility out of poverty and into the middle class in Latin American countries and a secondary or higher education is associated with higher probabilities of upward mobility compared to a primary education. Furthermore, these results are relatively consistent across Latin American countries (Ferreira, et al., 2013). Gindling and Trejos (2012) have shown that changes in the level of inequality in Costa Rica are driven primarily by changes associated with education. 
The education of the head of the household is typically used in micro-mobility studies. Using conditional micro-mobility analysis, it is found that an additional year of schooling by the head of the household has a positive effect on changes in per capita income. Controlling for initial per capita income, education has a significant and positive impact on absolute gains in income for Indonesian, South African, and Venezuelan households (Fields, et al., 2007). Fields (2011) notes other studies that find education provides a positive and significant impact on conditional micro-mobility.

Intra-generational income mobility studies that focus on poverty dynamics also find that education is a critical factor. It is found that a lack of a formal education greatly increases the chances of not escaping chronic poverty, or always being below the poverty line, in Peru (Herrera, 2009). Slon and Zuniga (2006) find that better educated households in Costa Rica are more likely to exit poverty, while a household with a head that has little education is much more likely to fall into poverty. It is also found that Costa Rican households with a better-educated head of household are much more likely to never experience poverty (Gindling, Trejos, \& Rowe, 2013). A better-educated head of household also reduces the chances of a non-poor household in one year falling below the poverty line in the next year (Gindling, et al., 2013).

Other types of economic mobility studies also find that education has a positive and significant impact on intra-generational mobility. In an analysis of dynamic movements above and below the minimum wage in Costa Rica, less educated workers are more likely to be at risk of falling below the legal minimum wage. However, better-educated workers are more likely to escape sub-minimum wage employment (Gindling \& Trejos, 2010).

Potential problems with the analysis of income mobility are also discussed in the literature. One potential problem is measurement error. This problem is caused by underreporting or misreporting total household income in a given time period (Fields, 2011). Measurement error can lead to potential biased results, especially in the coefficient on initial income. Another conspicuous problem is non-random attrition bias. Households may drop out of the panel survey across years at a non-random rate, which can lead to bias estimates of the impacts of the correlates (Fields, 2011).

\section{DATA AND METHODOLOGY}

\section{A. Data}

This paper analyzes conditional intra-generational income mobility in Costa Rica at the household level, in both absolute and relative terms. In order to conduct an analysis of income mobility, a panel data set for Costa Rican households is necessary, since it is not possible to analyze the movements of units over time without a panel data set (Fields, et al., 2007).

Data used for the analysis of Costa Rican households is constructed from the Households Surveys for Multiple Purposes (EHPM) from 2001 to 2007, conducted by the Costa Rican Institute of Statistics and Census (INEC). Each cross-sectional survey consists of around 40,000 individuals and 10,000 households, or about one percent of the population in Costa Rica. INEC and the Institute for Research in Economic Sciences (IICE) of the University of Costa Rica constructed the panel data set from cross-sections from the EHPM (Gindling \& Trejos, 2010). The construction of a panel data set was possible because each year the EHPM uses a rotating sample design where a given household is surveyed for up to four consecutive years before being rotated out of the sample. The survey includes a unique identifier variable which allows for households to be matched up for two or more years. Working with INEC, the IICE was able to match approximately sixty percent of all observations for at least two years (Gindling \& Trejos, 2010). For the purpose of this study, the analysis will focus on the six year-to-year transitions for households in Costa Rica between 2001 and 2007 (2001 to 2002,2002 to 2003 , etc.). 
The determinants of absolute and relative income mobility for these annual transitions will be analyzed in this study using regression analysis. In studying absolute income mobility, we will use Ordinary Least Squares (OLS) regressions where the dependent variable will be the change in the natural logarithm of per capita total household income. Changes in the natural logarithm of per capita total household income are used for several reasons. The first reason is for ease of interpretation, because changes in the natural logarithm of per capita income approximate percent changes in income gains. It also is useful since it is consistent with diminishing returns from the utility function (Fields, 2003). Also, the distribution of per capita household income tends to be skewed, with a large number of households at the bottom of the distribution and few households at the very top. The distribution of the natural logarithm of per capita income and changes in the natural logarithm of per capita income more closely approximate a normal distribution.

The analysis of relative income mobility will focus on changes among quintiles in the household income distribution. From per capita total household income, quintiles are created to analyze relative positional movements. Therefore, the dependent variable will be a categorical variable indicating directional movement in relative income mobility. The three directional movements categorized are a household moving up, staying within, or falling among quintiles.

One key explanatory variable in both the absolute and relative income mobility equations is the initial level of household per capita income (Fields, 2011). The coefficient on initial income indicates if conditional income mobility is convergent, divergent, or neither (not statistically significant). A negative coefficient on initial household income indicates convergence, where the lowest earners gain the most. Conversely, a positive coefficient on initial household income shows divergence, since the highest earners gain the most. The results in the literature regarding income convergence are mixed, with studies in some countries finding income convergence and studies in others countries finding income divergence (at least after controlling for other factors that affect income mobility; Fields, 2011).

As noted in the literature review, changes in per capita household income depend on changes in household size and changes in the use and returns to endowments of factors of production. Changes in household size can decrease household per capita income if there is an increase in nonworking dependent members, while an increase in working household member could contribute to an increase in per capita household income. Therefore, in addition to the change in household size we also include as explanatory variables the change in the number of children, the change in the number of dependents relative to income earnings and the change in the number of working age members of the household. Changes in the structure of the household can also be important. For example, it can be difficult for single parents to both care for children and maintain well-paid employment, so that single-parent status is often associated with low household income. Therefore, we include a variable indicating if the household becomes a single parent household or if a single parent becomes married.

Changes in the labor market status of household members also has an important influence on changes in household per capita income. Changes in the labor market status of the household head have been shown to be especially important, and we separately examine changes in the labor force characteristics of the head of the household and changes in the labor force characteristics of the entire household. The labor characteristics of the head of the household include employment status, sector of employment, whether the household head is self-employed, is an employee in a micro firm, is an employee in a large firm, and whether the head belongs to a union or solidarity organization. Labor force characteristics of the household include variables such as the unemployment rate of the household, the number of workers in the household (by education level), and the number of workers in the household who belong to a union or solidarity organization.

Another set of variables are the levels of endowments. For example, the education level of the household head has been shown to promote income mobility in Costa Rica (Slon and Zuniga, 2006). Another explanatory variable, age of the household head, captures patterns of income growth across 
the life cycle where earnings tend to increase with age (but at a decreasing rate). The gender of the household head may matter as women tend to earn less than equally qualified men. Immigrants are likely to have access to less social capital than the Costa Rican-born, and therefore we expect households headed by immigrants to exhibit less income mobility. Access to better income earning opportunities, as well as access to social capital, may vary by region. Therefore we also include a set of dummy variables indicating region of the country. Finally, we include a dummy variable for each year to control for macroeconomic changes that might have occurred from year to year.

\section{B. Methodology}

The analysis of income mobility will be divided into two parts. The first part is an unconditional analysis of quintile transitions. Transitions among quintiles in the distribution of household per capita income will be examined for all households. These provide an overview of the magnitude of relative income mobility among households. The second part will be a multivariate analysis of the characteristics of households that exhibit more or less absolute and relative income mobility.

It is standard in the literature to examine the determinants of changes in absolute income using Ordinary Least Squares regressions where logged household income is assumed to be a function of a vector of time-variant characteristics and a vector of changes in time-varying characteristics (i.e. Fields \& Sanchez-Puerta, 2010; Dercon \& Shapiro 2007). Specifically:

$$
\Delta Y_{i t}=\alpha+\beta Y_{i t}+Z_{i t} \delta+\Delta X_{i t} \gamma+\varepsilon_{i t}
$$

Where $\mathrm{i}$ indicates the household, $\mathrm{t}$ indicates the year, $\Delta \mathrm{Y}_{\text {it }}$ is the change (between time $\mathrm{t}$ and $t+1)$ in the natural log of per capita household income, $Y_{i t}$ is the initial level of the log of per capita household income, $\mathrm{Z}$ are the initial levels of characteristics and $\mathrm{X}$ are changes in characteristics (described above). We report both the OLS coefficients and the standardized, or Beta, coefficients from this regression. The OLS coefficient on a specific variable measures the percent change in income that results from a one-unit increase in that explanatory variable. The relative magnitudes of the standardized, or Beta, coefficients indicate which of the independent variable quantitatively has the "most important" impact on the dependent variable; a larger Beta coefficient on a particular variable indicates that variable has a more important impact on changes in per capita household income. ${ }^{5}$

To study the determinants of relative income mobility the dependent variable will be a multinomial variable that takes on three values: the household stays in the same quintile between time $t$ and $t+1$, the household moves to a higher quintile from time $t$ to $t+1$ or the household moves to a lower quintile from $t$ to $t+1$. The correlates of these transitions are then estimated using the multinomial logit technique. Specifically, the framework will be set up as follows:

$$
\operatorname{Prob}\left(\text { Quintile Movement }{ }_{j, i, t}\right)=\frac{\exp \left(\alpha+\beta_{j} Y_{i t}+Z_{i t} \delta_{j}+\Delta X_{i t} \gamma_{j}+\varepsilon_{i t}\right)}{1+\sum_{z \neq j} \exp \left(\alpha+\beta_{z} Y_{i t}+Z_{i t} \delta_{z}+\Delta X_{i t} \gamma_{z}+\varepsilon_{i t}\right)}
$$

Where $\mathrm{j}$ indicates three possible transitions: household i stays in the same quintile, household i moves to a higher quintile or household i moves to a lower quintile.

\footnotetext{
$5 \quad$ Specifically, the standardized, or Beta, coefficients measure by how many standard deviations the dependent variable changes when the independent variable changes by one standard deviation. Unlike the OLS coefficients, the magnitudes of the standardized, of Beta, coefficients do not depend on the units used to measure the dependent and independent variables.
} 


\section{RESULTS}

\section{A) Transition Matrix}

The analysis of income mobility in Costa Rica begins with the observation of transitions among quintiles (Table 1). This provides a basic tool to see how much mobility among different parts of the income distribution is occurring in Costa Rica. It is also important to note that these quintile movements reported in Table 1 are relatively short-term transition of one year.

The most notable feature of the examination of relative income mobility in Costa Rica is persistence in the top quintile. That is, households that start out in the top are much more likely to stay within their quintile than households in the middle quintiles. Of households that begin in the top quintile, 68 percent remain in place in the top quintile. Households in the second, third, and forth quintiles display more relative mobility, with 40 percent or fewer of households that begin in these quintiles staying in the same quintile (see the diagonal elements of the matrix in Table 1). Households who are initially in the bottom (poorest) quintile exhibit less mobility than those in the middle quintiles but more mobility than in the top quintile. Mobility out of the bottom quintile is still substantial; $43 \%$ of households who began in the poorest quintile in one year move to a higher income quintile the next year, suggesting that the majority of low-income families in Costa Rica are not trapped in a state of poverty.

TABLE 1

AVERAGE ONE-YEAR QUINTILE TRANSITIONS 2001-2007

\begin{tabular}{|c|c|c|c|c|c|c|c|}
\hline \multicolumn{8}{|c|}{ Years 2} \\
\hline & Quintile & Quintile 1 & Quintile 2 & Quintile 3 & Quintile 4 & Quintile 5 & Total \\
\hline \multirow[t]{5}{*}{ Year 1} & Quintile 1 & $57 \%$ & $25 \%$ & $11 \%$ & $5 \%$ & $2 \%$ & $100 \%$ \\
\hline & Quintile 2 & $24 \%$ & $38 \%$ & $23 \%$ & $11 \%$ & $4 \%$ & $100 \%$ \\
\hline & Quintile 3 & $12 \%$ & $24 \%$ & $35 \%$ & $22 \%$ & $7 \%$ & $100 \%$ \\
\hline & Quintile 4 & $5 \%$ & $12 \%$ & $23 \%$ & $40 \%$ & $19 \%$ & $100 \%$ \\
\hline & Quintile 5 & $2 \%$ & $3 \%$ & $7 \%$ & $20 \%$ & $68 \%$ & $100 \%$ \\
\hline
\end{tabular}

Households who do change quintiles are most likely to move up or down one quintile, but there are also a substantial number of households that move two quintiles; very few households move more than two quintiles in one year. Households are equally likely to move to a higher quintile as they are to move to a lower quintile. That is, the data in Table 1 suggests that while there is substantial movement of households between quintiles in the income distribution, the level of income inequality may not change very much from year to year. Gindling and Trejos (2013) present changes in the Gini coefficient in Costa Rica over this period and show that, indeed, the Gini coefficient changed very little between 2001 and 2007 (it fell slightly from .50 to .48).

Comparisons of quintile movements from other Latin American countries helps provide context for the quintile movements in Costa Rica. Most studies of income mobility in Latin America are intergenerational or over longer periods than those studied in this paper. We could find only one other study that reports year-to-year income mobility estimates. Fields \& Sanchez-Puerta (2010) studied the year-to-year income mobility of workers between earnings quintiles for urban Argentina households between 2001 and 2002. Similar to Costa Rica, the highest persistence is in the poorest and the richest quintiles. The persistence of the top quintile is similar to Costa Rica for the one-year transitions, but the bottom quintile shows slightly more mobility in urban Argentina. Furthermore, urban Argentina households showed more persistence in the middle of the distribution (the third 
and fourth quintiles) compared to Costa Rica. However, workers in urban Argentina households in the initial second, third, and forth quintiles showed a higher chance of rising one quintile instead of falling one quintile compared to Costa Rica, where Costa Rican households in the initial second and third quintiles showed a slightly higher chance of falling one quintile instead of rising one quintile. It is important to remember that Fields \& Sanchez-Puerta (2010) measure earnings mobility among workers while this paper presents income mobility among households, and it is likely that earnings of individual workers will be less stable than the incomes of households (because households may adjust the labor force participation of different household members to smooth out household income over time).

Comparisons of mobility in Costa Rica to countries outside of Latin America provides additional context. For example, there is more income mobility in Costa Rica in the 2000's than in the United States during the 1970's. Examining the one-year transition from 1974 to 1975, almost 69 percent of US households in the first quintile in 1974 remained in the same quintile in 1975, while almost 80 percent of US households in the fifth quintile in 1974 remained in the top quintile in 1975 (Gottschalk, 1997). Costa Rican households also displayed more mobility among the middle quintiles as well compared to households in the United States. Almost half of the US households in the second and third quintiles remained in those quintiles, while 58 percent of the households in forth quintile stayed in the fourth quintile (Gottschalk, 1997). These levels of persistence are much higher than households in Costa Rica, where persistence was 40 percent or less in the middle quintiles.

\section{B) Multivariate Analysis of the Determinants of Absolute Income Mobility}

Several interesting results emerge from the estimation of equation 1, which are reported in Table 2. First, absolute income mobility appears to be conditionally convergent, since the coefficient on initial per capita total household income is negative. This means that over the 2001-2007 period the lowest income households experiences larger increases in income, on average, than did the highest income households, holding other factors constant.

Table 2 reports both the OLS coefficients and the standardized, or Beta, coefficients. As noted, the relative magnitudes of the standardized, or Beta, coefficients indicate which of the characteristics are the "most important" influences on the growth and decline in household income. The Beta coefficients indicate that the most important variable explaining the change in household income is, in fact, initial per capita income.

The second most important set of variables are those that capture changes in employment status; aside from initial per capita income the single largest Beta coefficient is on the number of employed male household members. The impact on income of more employed household members is greater if the new employee is male rather than female (and the difference is statistically significant). If an additional male in the household becomes employed, household income increases by 31 percent, while an additional employed woman causes household income to increase by 21 percent. An additional household worker has a statistically significant larger positive impact on income if the additional worker has a secondary education or higher. This is not surprising as education is generally the most important measureable factor correlated with a higher level of earnings. An increase in hours worked for household heads already employed also has a large impact on household income. On the other hand, if the household unemployment rate (the number of household unemployed members to household labor force members) rises by 1 percent, income falls by 18.2 percent, and if a household head becomes unemployed, the household per capita income falls by 15.5 percent.

Moving into the formal sector is also correlated with an increase in per capita family income; obtaining a job where the employer pays the social security tax, moving to a large firm, becoming 
a paid employee all have statistically significant and relatively large standardized, or Beta, coefficients. Moving from any other sector into agriculture is associated with a reduction in per capita household income. Interestingly, moving into self-employment also increases per capita family income. After controlling for these changes, entering a union or solidarity organization is not a significant determinant of changes in per capita household income.

The third most important set of factors explaining changes in per capita household income are related to changes in the size of the household, especially the number of dependents vs. the number of working members. The Beta coefficient on the variable measuring change in the size of the household is the largest for any variable except initial income and the number of employed male family members. The negative coefficients on the household size variables indicate that an increase in the number of people in the household, especially if the number of income earnings in the household does not change, will lower per capita household income.

The fourth most important factor explaining changes in per capita household income is the education level of the household head. Compared to households with a head that has a primary education, households with a head that has less than a primary education display lower income gains. For example, the results suggest that the annual increase in income for a household where the head has less than a primary education was 10.9 percent lower than in a household where the head had a primary education. Similarly, a household with a head that has a secondary education or some college education display higher income gains than a household with a head that has a primary education. The biggest difference is between those with a secondary and college education; annual income growth for households where the head has college education is 10 percent greater than for households where the head has only a secondary education. That is, not only do households with more educated members start out with higher household incomes, over time the difference between the incomes of households with more educated heads and less educated heads becomes larger. This finding of a growing gap in absolute income mobility between workers at different education levels corroborates the findings of increased returns to education in Costa Rica (Gindling \& Trejos, 2012).

Another important factor explaining changes in per capita household income is the age of the household head. The OLS coefficients on age and age squared indicate that household income increases as the age of the household head increases, but at a decreasing rate. ${ }^{6}$ This is consistent with the pattern of income and earnings growth generally observed over the life cycle, where earnings increase with age, but at a decreasing rate.

The multivariate analysis also reveals other statistically significant factors that affect absolute income mobility but have a smaller impact than the factors discussed above (as measured by the Beta coefficient). Gender, region of the country and immigrant status of the head of the household all have statistically significant impacts on absolute income mobility. Households with a female head display lower gains in income than households with a male head. Urban households in the Central Valley display greater absolute income growth than rural households in other regions. And households where the head is an immigrant experience slower income growth than non-immigrant households. Becoming a single parent is significantly correlated with falling household income. Surprisingly, entering into a domestic partnership also significantly reduces household income, while entering a marriage does not have a statistically significant impact on household income.

Finally, incomes are more likely to increase if the economy is growing. The coefficients on the year dummy variables are largest in those years when economic growth rates are highest, in 2006 and 2007. Economic growth rates were 7.9 percent and 6.8 percent, respectively, in 2006 and 2007, compared to 0.3 (2001), 2.4 percent (2002), 5.6 percent (2003), 3.9 percent (2004) and 5.9 percent (2005).

6 Based on the estimated coefficients, family income never falls with age over the typical life span of a head of household. 
TABLE 2

OLS REGRESSION RESULTS OF CHANGES IN PER CAPITA INCOME

\begin{tabular}{|c|c|c|c|c|}
\hline Variable & Coefficient & Signficance & $\begin{array}{l}\text { Standard } \\
\text { Error }\end{array}$ & \begin{tabular}{|l|} 
Standardized \\
Coefficients \\
\end{tabular} \\
\hline Initial Income Per Capita & -0.348 & 0.0046 & $* * *$ & -0.471 \\
\hline \multicolumn{5}{|l|}{ Head of Household Characteristics (levels) } \\
\hline Age & 0.005 & 0.0014 & $* \star *$ & 0.099 \\
\hline Age Squared & -0.00003 & 0.00001 & ** & -0.058 \\
\hline Less Than a Primary Education $=1$ & -0.109 & 0.0096 & $* * *$ & -0.069 \\
\hline Primary Education $=1$ & Base & & & \\
\hline Less Than a Secondary Education $=1$ & 0.063 & 0.0111 & *** & 0.031 \\
\hline Secondary Education $=1$ & 0.169 & 0.0130 & $* * *$ & 0.072 \\
\hline Some College or College Degree $=1$ & 0.372 & 0.0128 & $* * *$ & 0.173 \\
\hline Female $=1$ & -0.047 & 0.0083 & $* * *$ & -0.029 \\
\hline Immigrant = 1 & -0.037 & 0.0131 & $* * *$ & -0.014 \\
\hline Urban = 1 & 0.089 & 0.0078 & $* * *$ & 0.062 \\
\hline \multicolumn{5}{|l|}{ Region of the Country } \\
\hline Central Valley $=1$ & Base & & & \\
\hline Chorotega $=1$ & -0.070 & 0.0118 & *** & -0.031 \\
\hline Pacific Central = 1 & -0.032 & 0.0121 & *** & -0.014 \\
\hline Brunca $=1$ & -0.056 & 0.0114 & $* * *$ & -0.026 \\
\hline Atlantic Huetar $=1$ & -0.035 & 0.0116 & *** & -0.016 \\
\hline North Huetar $=1$ & -0.008 & 0.0150 & & -0.003 \\
\hline \multicolumn{5}{|l|}{ Changes in Household Labor Force Characteristics } \\
\hline Change in Household Unemployment Rate & -0.182 & 0.0205 & $* * *$ & -0.053 \\
\hline Change in Household Employed Female Members & 0.210 & 0.0073 & *** & 0.172 \\
\hline Change in Household Employed Male Members & 0.307 & 0.0074 & $* * *$ & 0.274 \\
\hline Change in Employed Members with Secondary Education or More & 0.044 & 0.0079 & *** & 0.030 \\
\hline Change in Household Unionization Rate & 0.093 & 0.0230 & *** & 0.031 \\
\hline \multicolumn{5}{|l|}{ Changes in Head of Household Labor Characteristics } \\
\hline Household Head Becomes Unemployed & -0.155 & 0.0235 & 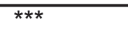 & -0.037 \\
\hline Change in Agriculture Sector Status (enter agriculture) & -0.093 & 0.0162 & *** & -0.030 \\
\hline Change in Manufacturing Sector Status (enter manufacturing) & -0.018 & 0.0155 & & -0.006 \\
\hline Change in Construction Sector Status (enter construction) & 0.062 & 0.0192 & $* * *$ & 0.017 \\
\hline Change in Social Security Status (gain social security) & 0.079 & 0.0138 & $* * *$ & 0.033 \\
\hline Change in Micro Firm Employment (enter micro firm) & -0.001 & 0.0094 & & -0.0005 \\
\hline Change in Large Firm Employment (enter large firm) & 0.033 & 0.0115 & $* * *$ & 0.016 \\
\hline Change in Self-Employed Status (become self-employed) & 0.070 & 0.0249 & $* * *$ & 0.033 \\
\hline Change in Paid Employee Status (become an employee) & 0.073 & 0.0255 & *** & 0.035 \\
\hline Change in Hours per Week & 0.003 & 0.0002 & $* * *$ & 0.060 \\
\hline Change in Union Status & -0.024 & 0.0223 & & -0.008 \\
\hline \multicolumn{5}{|l|}{ Changes in Household Demographic Characteristics } \\
\hline Change in Size of Household & -0.135 & 0.0061 & $* * *$ & -0.202 \\
\hline Change in Number of Children in Household & -0.006 & 0.0077 & & -0.006 \\
\hline Household Head Becomes Single Parent & -0.145 & 0.0187 & *** & -0.056 \\
\hline Household Head Becomes Married & -0.023 & 0.0154 & & -0.009 \\
\hline Household Head Enter Domestic Partnership & -0.088 & 0.0202 & *** & -0.034 \\
\hline Change in Household Working Age to Employed Ratio & 0.036 & 0.0028 & *** & 0.076 \\
\hline Change in Dependents to Recipients Ratio & -0.097 & 0.0066 & *** & -0.086 \\
\hline \multicolumn{5}{|l|}{ Year Dummy Variables } \\
\hline Year $2003=1$ & 0.068 & 0.0131 & *** & 0.034 \\
\hline Year $2004=1$ & 0.069 & 0.0133 & $* * *$ & 0.034 \\
\hline Year $2005=1$ & 0.165 & 0.0127 & $* * *$ & 0.087 \\
\hline Year $2006=1$ & 0.221 & 0.0126 & $* \star *$ & 0.122 \\
\hline Year $2007=1$ & 0.320 & 0.0123 & $* * *$ & 0.188 \\
\hline Constant & 3.501 & 0.0571959 & $* * *$ & - \\
\hline \multicolumn{5}{|l|}{$\mathrm{N}=26298$} \\
\hline
\end{tabular}




\section{C) Multivariate Analysis of the Determinants of Relative Income Mobility}

While absolute income mobility shows the impact of factors that affect absolute income gains, relative mobility analysis can help show the factors that affect the position of the household in the distribution of income per capita; that is, relative to the income of other households. Using a multinomial logit model, the marginal effects of each explanatory variable is estimated for three types of relative income change: falling into a lower quintile, rising into a higher quintile, or staying within the same quintile. The results are presented in Table 3, where the marginal effects of each variable on the probability that a household will make each type of change are reported (evaluated at the means of the independent variables).

As with the absolute income mobility regressions, the positive coefficient on the initial quintile of the household for falling quintiles and the negative coefficient on the initial quintile of the household for rising quintiles indicate conditional convergence. This corroborates the results found in the absolute income mobility analysis.

Consistent with the absolute income mobility results, changes in employment status are important in explaining movement in relative income mobility. Losing or gaining jobs is particularly important. If more household members become unemployed, or if the household head becomes unemployed, the probability of experiencing a fall in the relative household distribution increases. Similarly, an increase in the number of household members who are working is correlated with an increase in the probability that a household will move up in the relative income distribution. As with absolute income mobility, the impact of employment on mobility is larger if it is a male who gains or loses a job, relative to a female. Among employees, moving into the formal sector (large firm, paid employee and into a job where the employer pays social security taxes) is associated with an increase in the probability that a household will rise in the relative distribution of income. Becoming self-employed reduces the probability that a household will fall in the relative distribution of income.

Consistent with the results from the absolute income mobility equation, the following household demographic variables are correlated with a decrease in the probability of increasing the household's position in the distribution of per capita income and an increase in the probability of decreasing the household's position: an increase in household size, an increase in the proportion of dependents in the household, and becoming a single parent.

Consistent with the absolute income results, the following variables are correlated with an increased probability that a household will fall in the relative income distribution and a decreased probability that a household will rise in the relative income distribution: being in a female-headed household, being in a rural household and being in a household with a younger household head. Furthermore, households in the Chorotega and Brunca regions were more likely to fall in quintiles and less likely to rise in quintiles compared to households in the Central Valley region. Households with an immigrant head of household were 2.6 percent more likely to fall in quintiles compared to a non-immigrant household.

Education also plays an important role in relative income mobility. The marginal effects of the levels of education on rising among quintiles and falling among quintiles are all significant. The probability that a household will rise into a higher quintile increases as the education of the household head increases. Similarly, the probability that a household will fall into a lower quintile decreases as the education of the household head increases. Controlling for the initial quintile and other factors, households with a head that has less than primary education are 4.1 percent more likely to fall among quintiles and 7.3 percent less likely to rise among quintiles. In addition, these households are more likely to remain in their quintile than households with a head that has a primary education. Households with a head that has less than a secondary education are 4.1 percent less likely to fall among quintiles and 4.5 percent more likely to rise among quintiles than 
TABLE 3

MULTINOMIAL LOGIT RESULTS IN QUINTILE MOVEMENTS

\begin{tabular}{|c|c|c|c|c|c|c|c|c|c|}
\hline \multirow[b]{2}{*}{ Variable } & \multicolumn{3}{|c|}{ Fall in Quintile } & \multicolumn{3}{|c|}{ Stay in Quintile } & \multicolumn{3}{|c|}{ Rise in Quintile } \\
\hline & DyDX & & Std Error & DyDX & & Std Error & DyDX & & Std Error \\
\hline Initial Quintile & 0.114 & $* * *$ & 0.0023 & 0.007 & ** & 0.0028 & -0.121 & $* * *$ & 0.0024 \\
\hline \multicolumn{10}{|l|}{ Household Head Characteristics (levels) } \\
\hline Age of Head of Household & -0.004 & *** & 0.0011 & -0.002 & & 0.0013 & 0.006 & *** & 0.0011 \\
\hline Age-squared & 0.00002 & ** & 0.00001 & 0.00003 & *** & 0.00001 & -0.0001 & $* * *$ & 0.00001 \\
\hline $\begin{array}{l}\text { Less Than a Primary Education }=1 \\
\text { Primary Education }=1\end{array}$ & Base $^{0.041}$ & *** & 0.0077 & Base $^{0.032}$ & $* * *$ & 0.0086 & -0.073 & $* * *$ & 0.0066 \\
\hline Less Than a Secondary Education $=1$ & -0.041 & & 0.0075 & -0.004 & & 0.0101 & 0.046 & $* * *$ & 0.0093 \\
\hline Secondary Education $=1$ & -0.095 & *** & 0.0070 & 0.019 & & 0.0121 & 0.076 & $* * *$ & 0.0120 \\
\hline Some College or College Degree $=1$ & -0.194 & *** & 0.0047 & 0.147 & *** & 0.0118 & 0.048 & $* * *$ & 0.0119 \\
\hline Female $=1$ & 0.029 & *** & 0.0067 & -0.015 & * & 0.0075 & -0.014 & $* *$ & 0.0063 \\
\hline Immigrant = 1 & 0.026 & ** & 0.0108 & -0.011 & & 0.0120 & -0.015 & & 0.0099 \\
\hline Urban = 1 & -0.055 & *** & 0.0058 & -0.004 & & 0.0071 & 0.059 & $* * *$ & 0.0062 \\
\hline \multirow{2}{*}{\multicolumn{10}{|c|}{$\frac{\text { Region of the Country }}{\text { Central Valley }=1}$}} \\
\hline Central Valley $=1$ & Base & & & & & & & & \\
\hline Chorotega Region = 1 & 0.035 & *** & 0.0099 & 0.002 & & 0.0106 & -0.037 & *** & 0.0082 \\
\hline Pacific Central Region = 1 & 0.037 & *** & 0.0101 & -0.041 & $* * *$ & 0.0111 & 0.004 & & 0.0094 \\
\hline Brunca Region $=1$ & 0.028 & $* * *$ & 0.0095 & 0.004 & & 0.0102 & -0.032 & $* * *$ & 0.0079 \\
\hline Atlantic Huetar Region = 1 & 0.039 & *** & 0.0096 & -0.052 & *** & 0.0107 & 0.014 & & 0.0091 \\
\hline North Huetar Region $=1$ & 0.018 & & 0.0120 & -0.012 & & 0.0135 & -0.006 & & 0.0113 \\
\hline \multicolumn{10}{|l|}{$\begin{array}{l}\text { Changes in Household Labor Force } \\
\text { Characteristics }\end{array}$} \\
\hline Change in Household Unemployment & & & & & & & & & \\
\hline Rate & $0.101 *$ & *** & 0.0174 & -0.016 & & 0.0191 & -0.085 & $\star * * *$ & 0.0156 \\
\hline Change in Secondary Educated Workers & -0.011 & * & 0.0063 & -0.040 & *** & 0.0075 & 0.051 & $* * *$ & 0.0067 \\
\hline Change in Employed Male Workers & -0.154 & *** & 0.0063 & 0.006 & & 0.0071 & 0.148 & $* * *$ & 0.0060 \\
\hline Change in Employed Female Workers & -0.111 & *** & 0.0059 & 0.0001 & & 0.0068 & 0.111 & $* * *$ & 0.0058 \\
\hline Change in Union Rate & -0.039 & *** & 0.0112 & -0.012 & & 0.0136 & 0.052 & $* * *$ & 0.0124 \\
\hline \multicolumn{10}{|l|}{$\begin{array}{l}\text { Change in Head of Household Labor } \\
\text { Characteristics }\end{array}$} \\
\hline Household Head Becomes Unemployed & $0.094^{\prime}$ & ${ }_{* \star *}^{*}$ & 0.0205 & -0.065 & $* * *$ & 0.0224 & -0.028 & & 0.0183 \\
\hline Enters Agriculture Sector & 0.046 & *** & 0.0120 & -0.006 & & 0.0141 & -0.040 & $* * *$ & 0.0119 \\
\hline Enters Construction Sector & -0.031 & ** & 0.0144 & 0.007 & & 0.0171 & 0.024 & * & 0.0146 \\
\hline Gains Social Security & -0.043 & ** & 0.0107 & 0.010 & & 0.0125 & 0.032 & $* * *$ & 0.0106 \\
\hline Enter Micro Firm Employment & 0.016 & & 0.0072 & -0.011 & & 0.0085 & -0.005 & & 0.0072 \\
\hline Enter Large Firm Employment & -0.012 & & 0.0087 & -0.014 & & 0.0104 & 0.027 & $* * *$ & 0.0090 \\
\hline Becomes Self-Employed & -0.086 & *** & 0.0194 & 0.081 & *** & 0.0227 & 0.005 & & 0.0188 \\
\hline Becomes a Paid Employee & -0.081 & *** & 0.0197 & 0.066 & $* * *$ & 0.0232 & 0.015 & & 0.0193 \\
\hline Change in Hours Per Week & -0.002 & & 0.0002 & 0.0002 & & 0.0002 & 0.001 & $* * *$ & 0.0002 \\
\hline \multicolumn{10}{|l|}{$\begin{array}{l}\text { Changes in Household Demographic } \\
\text { Characteristics }\end{array}$} \\
\hline Change in the Size of Household & 0.063 & *** & 0.0050 & -0.008 & & 0.0057 & -0.056 & ${ }^{* * *}$ & -0.0557 \\
\hline Change in Number of Children & 0.003 & & 0.0063 & 0.023 & *** & 0.0072 & -0.026 & $* * *$ & 0.0061 \\
\hline Head Becomes a Single Parent & 0.066 & *** & 0.0146 & 0.014 & & 0.0174 & -0.080 & $* \star *$ & 0.0154 \\
\hline Head Becomes Married & 0.013 & & 0.0120 & 0.012 & & 0.0141 & -0.025 & $* *$ & 0.0121 \\
\hline $\begin{array}{l}\text { Head Enters Domestic Partnership } \\
\text { Change in Working Age to Employed }\end{array}$ & 0.025 & & 0.0156 & 0.028 & & 0.0188 & -0.053 & $* * *$ & 0.0167 \\
\hline Member Ratio & -0.005 & & 0.0025 & 0.007 & *** & 0.0027 & -0.002 & & 0.0022 \\
\hline Change in Dependent to Recipient Ratio & 0.060 & *** & 0.0059 & -0.040 & *** & 0.0063 & -0.019 & *** & 0.0049 \\
\hline$N=26298$ & $\begin{array}{l}\operatorname{Prob}(Y= \\
\text { 1) }\end{array}$ & & 0.2158 & \begin{tabular}{|l}
$\operatorname{Prob}(\mathrm{Y}=$ \\
1)
\end{tabular} & & 0.5721 & $\begin{array}{l}\operatorname{Prob}(Y= \\
\text { 1) }\end{array}$ & & 0.2121 \\
\hline
\end{tabular}

*** Statistically Significant at the $1 \%$ level

** Statistically Significant at the $5 \%$ level

* Statistically Significant at the $10 \%$ level 
households with a head with a primary education. Households with a head with a secondary education were 9.5 percent less likely to fall among quintiles and 7.5 percent more likely to rise in quintiles, compared to households where the head had a primary education. Households with a head that has some college education were much less likely to fall in quintiles and much more likely to remain in the initial quintile compared to households with a head that has a primary education. Heads with some college education or a college degree were 10.4 percent less likely than heads with a secondary education to fall among quintiles, and 12.7 percent more likely to remain in their initial quintile.

\section{CONCLUSIONS}

The results from the analyses presented in this paper provide insight into year-to-year intragenerational income mobility of households in Costa Rica between 2001 and 2007. One finding is that income mobility is conditionally convergent in absolute and relative terms for Costa Rica between 2001 and 2007. That is, incomes tend to grow faster for households that start out with low incomes compared with income growth in households who begin with higher incomes. We also find that there is substantial mobility among quintiles in the per capita household income distribution, especially for the three middle quintiles. Comparisons to other countries suggest that there is more year-to-year relative income mobility in Costa Rica in the middle quintiles than in urban Argentina during a similar time period and there is substantially more mobility in Costa Rica compared to the United States.

Apart from initial per capita income, the three most important factors that explain changes in per capita household income in Costa Rica are, in order of importance: (1) changes in the employment status of household members; (2) changes in the number of dependents (children, elderly and other non-working members) in the household; and (3) the education of household members, especially the household head.

What happens in the labor market is clearly very important. Increasing the number of household members who are employed greatly increases the probability that a household will experience upward income mobility, both in absolute and relative terms, while more family members falling into unemployment, especially if that household member is the household head, tends to increase the probability that household income will fall in both absolute and relative terms. The more household members who work in the formal sector, the faster income will grow. And, if working household members do move into the formal sector, the probability that a household's relative income will fall diminishes, and vice-versa. Although formal sector work is the best promoter of upward income mobility, any type of work will help; if workers move from not working into self-employment, household income will increase. Conversely, if a household member loses her/his job then there is an increase in the probability that workers family will experience a fall in relative income. Consistent with this, it is more likely that the income of a family will increase if the aggregate economic growth rate, and therefore the probability of finding employment, is greater.

The structure and size of the household also matters. An increase in the number of dependent family members-either too young or too old to work-will reduce per capita family income growth, increase the probability of falling into poverty and decrease the probability of rising out of poverty. Households whose head becomes a single parent are likely to experience a drop in household income, even after controlling for household size. And households with young heads are more likely to fall, and less likely to rise, in the distribution of income.

Finally, education matters. The multivariate analysis reveals that levels of education are statistically significant in explaining movements in absolute and relative terms, and households with more educated members (especially the head) are more likely to exhibit both absolute and relative income mobility. A college degree strongly prevents downward mobility and increases retention in 
the initial quintile, which is usually the top quintile. On the other hand, a lack of a primary education prevents upward mobility and increases retention in the bottom quintile.

Our results suggest some recommendations for policies that could promote upward income mobility and protect households from downward income mobility. We have shown that what happens in the labor market is very important in driving year-to-year income mobility. When household members obtain a good job household income increases, and when family members lose jobs household income falls. This suggests that a macroeconomic policy that generates economic growth, and that has the creation of employment as one of its objectives, can promote upward income mobility. The importance of employment also suggests that policies that help to minimize income losses when family members lose jobs can help reduce downward income mobility. One such policy may be the transformation of the Fondo de Capitalización Laboral into a type of unemployment insurance.

A second important determinant of intra-generational income mobility are changes in the structure of the household. For example, an increase in the number of dependent family members, who are too young or too old to work and who may require care, makes it more likely that income will fall. This is especially true if the household is headed by a single parent. This suggests that providing for and subsidizing child care and/or elder care, which could make it easier for single parents to enter the labor force, could promote the upward income mobility of low-income households. Income transfers for single parent families with children of school age could also help protect these households for falling incomes.

Finally, we have shown that education promotes upward income mobility. This suggests that policies that promote educational attainment, especially among members of low-income households, can help promote upward income mobility. Subsidies to help low-income families pay for school supplies, school lunches, and the other costs of education can help. Conditional Cash Transfers, which provide income to low-income households on the condition that the children of those households attend school, can promote educational attainment while at the same time directly increasing the incomes of low-income households. To help adults already in the labor force, training programs that provide skills that increase employability can help promote upward income mobility.

\section{REFERENCES}

Baulch, B., \& Hoddinott, J. (2000). Economic Mobility and Poverty Dynamics in Developing Countries. Journal of Development Studies, 36(6), 1-24.

Dercon, S., \& Shapiro, J. S. (2007). Moving On, Staying Behind, Getting Lost: Lessons on Poverty Mobility from Longitudinal Data. In D. Narayan, P. Petesch (Eds.), Moving Out of Poverty. Volume 1. Cross-Disciplinary Perspectives on Mobility (pp. 77-126). Washington, D.C.: World Bank; Houndmills, U.K. and New York: Palgrave Macmillan.

Ferreira, F.H., Messina, J., Rigolini, J., Lopez-Calva, L.F., Lugo, M.A., \& Vakis, R. (2013). Economic Mobility and the Rise of the Latin American Middle Class. World Bank: Washington, D.C. Retrieved from http://web.worldbank.org/WBSITE/EXTERNAL/COUNTRIES/LACEXT/EXT LACOFFICEOFCE/0,,contentMDK:23311344 pagePK:64168445 piPK:64168309 theSite PK:870893,00.html

Fields, G. S., \& Sanchez Puerta, M. (2010). Earnings Mobility in Times of Growth and Decline: Argentina from 1996 to 2003. World Development, 38(6), 870-880. doi: http://dx.doi. org/10.1016/j.worlddev.2010.02.001

Fields, G. (2011). What We Know (and Want to Know) About Earnings Mobility in Developing Countries. Retrieved [2/29/2012], from Cornell University, ILR School site: http:// digitalcommons.ilr.cornell.edu/workingpapers/154/ 
Fields, G. (2008). Income mobility [Electronic verison]. Retrieved Oct. 23, 2013, from Cornell University ILR School site: http://digitalcommons.ilr.cornell.edu/articles/453/

Fields, G. S., Duval Hernandez, R., Freije, S., \& Sanchez Puerta, M. (2007). Intragenerational Income Mobility in Latin America. Economia: Journal Of The Latin American And Caribbean Economic Association, 7(2), 101

Fields, G., Chichello, P, Freiji, S., \& Newhouse, D. (2003). Household income dynamics: A fourcountry story. Journal of Developmental Studies, 40(2), 30-54

Gindling, T. H. \& Trejos, J. D. (2004). Inequality in Central America in the 1990s. Cepal Review, 175196. Retrieved from http://www.cepal.org/publicaciones/xml/8/22348/G2258iTrejosGindling.pdf

Gindling, T. H. \& Trejos, Juan Diego (2010). Improving the Compliance with Legal Minimum Wages in Costa Rica (UMBC Working Paper No. 10-127), June. Retrieved from http://www.umbc.edu/ economics/wpapers/wp_10_127.pdf

Gindling, T. H. \& Trejos, J. D. (2013). The distribution of income in Central America. IZA Working Paper No. 7236, February. Retrieved from http://ftp.iza.org/dp7236.pdf

Gindling, T. H. , Trejos, J. D., \& Rowe, S. (2012). Factors affecting poverty dynamics in Costa Rica. Unpublished working paper.

Gottschalk, P. (1997). Inequality, income growth, and mobility: The basic facts. Journal of Economic Perspectives. Vol 11(2): pp. 21-40

Grawe, N. (2008). Education and Economic Mobility. Urban Institute: Washington, D.C. Retrieved from http://www.urban.org/UploadedPDF/1001157_Education.pdf

Haskins, Ron (2008) Education and Economic Mobility. Brookings Institute. Retrieved from http:// www.brookings.edu/ /media/Research/Files/Reports/2008/2/economic\%20mobility\%20 sawhill/02_economic_mobility_sawhill_ch8.PDF

Herrera, J. (2001). Poverty Dynamics in Peru, 1997-1999. Document De Travail. Developpement et insertion internationale.

Slon, P. \& Zuniga, E. (2006). Poverty Dynamics in Costa Rica with Panel Data from Cross-sections. Cepal Review, 165-178. 
